Archives of Agriculture and Environmental Science

\title{
Impacts of sediment mining on the hydrochemistry and macrozoobenthos community in a coastal lagoon, Lagos, Nigeria
}

\section{J.A. Nkwoji ${ }^{*}$ (D) and S.I. Awodeyi}

Benthic Ecology and Hydrobiology Unit, Department of Marine Sciences, University of Lagos, Lagos, NIGERIA "Corresponding author's E-mail: jnkwoji@unilag.edu.ng

\section{ARTICLE HISTORY}

Received: 17 July 2018

Revised received: 02 August 2018

Accepted: 12 August 2018

\section{Keywords}

Coastal lagoon

Hydrochemistry

Macrozoobenthos

Sediment mining

\begin{abstract}
The water chemistry and macrozoobenthos assemblage of ten study stations in the Lagos lagoon were studied from December 2016 to May 2017 to assess the impacts of sediment mining on the water quality and the biological indices of the macrozoobenthos. Water and composite benthic samples were collected monthly at each study station and analysed in the laboratory following standard procedures. Except temperature, $\mathrm{pH}$, TSS, salinity and conductivity showed no significant $(P>0.05)$ difference, while the other parameters were not significantly $(P<0.05)$ different among the stations. The sediment grain size analysis of the study area indicated the dominance of sand in sediment. This could be as a result of the dredging of the study area as Lagos lagoon is originally known to have muddy substratum. A total of 1,237 organisms belonging to 3 phyla, 4 classes, 10 families and 10 Species were recorded during the study period. Analysis of benthic community structure of the study area reveals a community dominated by mollusks, with the Bivalve, Aloides trigona contributing $54 \%$ and the gastropod, Pachymelania aurita contributing $33 \%$ of the total benthic fauna assemblage during the period of study. The fluctuations in the physicochemical parameters, sediments, and the composition, abundance and diversity of the macrobenthic fauna of the study area were largely influenced by the anthropogenic activities. In particular, stations with pronounced sediment mining activities recorded highly turbid water, changed substratum type and defaunisation.
\end{abstract}

(C)2018 Agriculture and Environmental Science Academy

Citation of this article: Nkwoji, J.A. and Awodeyi, S.I. (2018). Impacts of sediment mining on the hydrochemistry and macrozoobenthos community in a coastal lagoon, Lagos, Nigeria. Archives of Agriculture and Environmental Science, 3(3): 209-215, https://dx.doi.org/10.26832/24566632.2018.030301

\section{INTRODUCTION}

The act of sediment mining has serious environmental implications on the estuarine ecosystem. In the Lagos lagoon, the incessant sediment mining with its associated contaminant upload threatens the ecosystem services that the benthic fauna provide (Sogbamu et al., 2016). The survival of the benthic organisms is hampered owing to sediment plume, and the change in the chemical characteristics of the water column will impact negatively on the activities of the photosynthetic microphytes. As a result of the increase in suspended sediments produced by mining activity, planktotrophic and lecithotrophic larvae of benthic organisms would be buried by the settling sediment particles from overlying water (Nuttall and Bielby, 1973). Habitat distortion and removal of sediment top would lead to erosion of the epifauna and ultimately, to loss of biodiversity. Sediment mining, in addition to the direct physical disturbance of the habitat, often produces long range impacts on communities downstream which are not in the immediate sphere of activity. The impact of suspended solids on benthic fauna has long been studied. High levels of turbidity as well as siltation as a result of sand mining are known to have negative effects on species diversity (Chutter, 1969).

Benthic fauna perform a variety of roles that are essential for the proper functioning and health of the aquatic ecosystem (Wallace and Webser, 1996). The benthic secondary production serves as natural food source to pelagic and bentho-pelagic community. They accelerate detrital decomposition (Van de 
Bund et al., 1994, Wallace and Webster, 1996) thereby making food available for the detrital and deposit feeders. The benthic fauna also release bound nutrients into solution by feeding activities, excretion and burrowing into the sediment (Covich et al., 1999). Benthic fauna play key roles in the cycling of nutrients and controlling nutrient outflows from the ecosystems by transforming organic detritus from sedimentary storage into dissolved nutrients (Barnes and Hughes, 1988; Covich, 1999).

The distribution of benthic communities is not continuous but patchy and influenced by several factors such as food distribution, environmental impacts, water flow and quality, dissolved oxygen and sediment stability. Biogeochemical processes that take place in the sediment create significant horizontal and vertical heterogeneities in the substrata that provide a physical template for distinct niches (Covich et al., 1999). According to Teixeira et al. (2012), sediment characteristics have great influence on the spatial structure of benthic assemblages. Recently, sediment mining has become more intense in the Lagos lagoon and its adjourning water bodies. The construction industry has created huge opportunities in the area of sediment mining for both skilled and unskilled labour in Lagos. Sand dredging in some places has been largely responsible for the loss of breeding habitats for sea turtles, which depend on sandy beaches for their nesting. Sediment mining could also permanently alter and destroy marine habitats, breeding, spawning and feeding areas of fish stock both within the mined area and surrounding area, raised turbidity impacting on many species, increased organic fallout causing oxygen depletion and die off, burial and smothering of seabed organisms in the mining and surrounding areas. This study seeks to investigate the effects of sediment mining on the hydrochemistry and the benthic macrofauna community of the coastal lagoon of Lagos, Nigeria.

\section{MATERIALS AND METHODS}

\section{Study area}

The study area (Figure 1 ) is located between latitude $6^{\circ} 26^{\prime} \mathrm{N}$ and $6^{\circ} 38^{\prime} \mathrm{N}$ longitude $3^{\circ} 23^{\prime} \mathrm{E}$ and $3^{\circ} 43^{\prime} \mathrm{E}$ and is a major part of the barrier-lagoon complex of the Nigerian coastal zone. The barrier-lagoon complex extends eastwards for about $200 \mathrm{~km}$ from the Nigerian-Benin Republic border to the western limit of the Transgressive Mud Coast and covers an area of about 208 $\mathrm{km}^{2}$ (FAO, 1981). The Lagos lagoon empties into the Atlantic Ocean at the Lagos Harbour. The Lagos lagoon is a great expanse of shallow waters and is generally between $0.5-2 \mathrm{~m}$ deep in most parts but more is more than $5 \mathrm{~m}$ in some dredged parts of the lagoon. The interconnecting creeks are also very shallow and are sites of active silting and deposition of mud. The lagoon sediments range between mud, sandy mud, muddy sand, and sand (Ajao and Fagada, 1991). Ten sampling stations were selected for this study along the north-western axis of the lagoon taking into consideration, the extent of sediment mining and dredging and its ecological impacts on the coastal lagoon. The exact locations of the stations were determined with the aid of the global positioning system (GPS).
Collection and analysis of samples

Water temperatures, dissolved oxygen (DO) and total dissolved solids (TDS) were measured in-situ at every sampling station with mercury in glass thermometer, hand held LaMotte DO Meter (DO 6 PLUS) and LaMotte TDS Meter (TDS 6 PLUS) respectively. Water samples were collected at stations at subsurface level in $\mathrm{Idm}^{3}$ sterile capped containers following the methods described by APHA (2005). Sampling bottles were kept in large, airtight plastic ice-cold cooler at $4^{\circ} \mathrm{C}$ and were transported to standard laboratory for analysis. The $\mathrm{pH}$, conductivity, turbidity and salinity were measured in the laboratory with water quality checker (Horiba-U10). Separate water samples were collected in $250 \mathrm{ml}$ dissolved oxygen bottles at each station and incubated in a dark cupboard for five days for completion of 5 day biochemical oxygen demand determination as determined by APHA (2005).

Monthly composite benthic samples were collected with the use of Van-Veen grab $\left(0.25 \mathrm{~m}^{2}\right)$ at each study area. Part of the sample for each study station was preserved in an aluminium foil paper for sediment grain size analysis in the laboratory. The remaining samples were sieved through $0.5 \mathrm{~mm}$ sieve. The materials retained on the sieve were stored in plastic container and preserved in $5 \%$ formalin for further analysis. The fixed samples were transported to the Benthic Ecology Laboratory in the Department of Marine Sciences, University of Lagos for analysis. Sorting of the samples was done with the aid of a handheld magnifying lens to get the clean samples of the macrozoobenthos. The sorted macrozoobenthos were counted and identified to species level where possible, and the numbers recorded. Identification of the benthic macrozoobenthos was done after Edmunds (1978), Barnes (1980), Fischer et al. (1981), Hayward and Ryland (1995) and Yankson and Kendall (2001).

\section{Analysis of data}

The statistical package for social sciences (SPSS11.0) Windows application and Microsoft Excel were adopted for the data analyses. Analysis of variance was calculated for the physicochemistry across study stations while PAST statistical program was used to compute the biological indices such as Margalef's index for species richness, Shannon-Wiener and Simpson's indices for species diversity, and the Equitability index for evenness of the community. The diversity indices were computed following description by Ogbeibu (2005) as follows.

\section{Margalef's species richness index}

The Species richness index (d) was used to evaluate the community structure. The equation below was applied and results were recorded to two decimal places.

$$
\mathrm{d}=\frac{s-1}{\ln N}
$$

Where:

$d=$ Species richness index;

$S=$ Number of species in a community;

$N=$ Total number of individuals in species. 
Shannon and Wiener diversity index $(\mathrm{H})$

Shannon and Wiener diversity index $(H)$ is given by the equation:

$$
\mathrm{Hs}=\frac{N \log N-\sum P^{i} \log P i}{N}
$$

Where:

$\mathrm{Hs}=$ Shannon and Wiener Diversity Index

$i=$ Counts denoting the $i$ th species ranging from $i-n$

$\mathrm{Pi}=$ Proportion that the ith species represents in terms of numbers of individuals with respect to the total number of individuals in the sampling space as whole.

Species equitability or evenness index

Species Equitability or Evenness index (j) (Ogbeibu, 2005) was used to calculate how evenly the species are distributed in a community. It is determined by an equation.

$$
\mathrm{J} \frac{H s}{\log _{2} S}
$$

Where:

$J=$ Equitability index;

$\mathrm{Hs}=$ Shannon and Wiener index;

$\mathrm{S}=$ Number of species in a community;

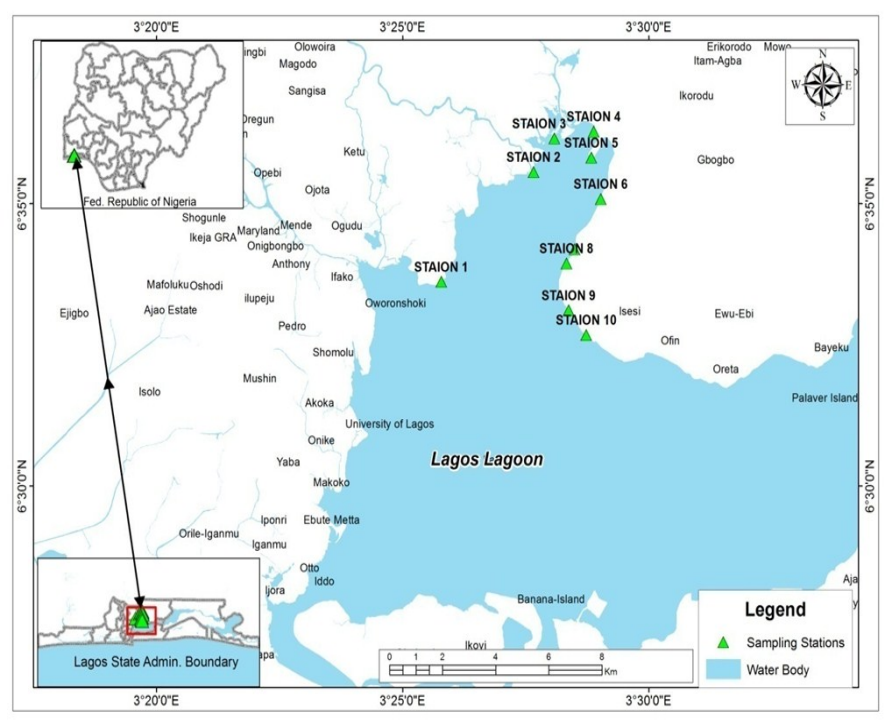

Figure 1. Map of the Lagos Lagoon showing study sites.

\begin{tabular}{|c|c|c|c|}
\hline Station no. & Location & Average depth (m) & Coordinates \\
\hline 1 & Agboyi & 2.2 & Latitude N $06^{\circ} 33^{\prime} 37.0^{\prime \prime}$, Longitude E $003^{\circ} 25^{\prime} 47.4^{\prime \prime}$ \\
\hline 2 & Magidun entrance & 11.1 & Latitude N $06^{\circ} 35^{\prime} 33.8^{\prime \prime}$, Longitude E $003^{\circ} 27^{\prime} 40.4^{\prime \prime}$ \\
\hline 3 & Magidun II & 4.0 & LatitudeN $06^{\circ} 36^{\prime} 09.4^{\prime \prime}$, Longitude E $003^{\circ} 28^{\prime} 05.3^{\prime \prime}$ \\
\hline 4 & Ogolonto & 2.7 & LatitudeN $06^{\circ} 36^{\prime} 16.9^{\prime \prime}$, Longitude E $003^{\circ} 28^{\prime} 53.4^{\prime \prime}$ \\
\hline 5 & NPA & 1.6 & LatitudeN $06^{\circ} 35^{\prime} 49.0^{\prime \prime}$, Longitude E $003^{\circ} 28^{\prime} 50.4^{\prime \prime}$ \\
\hline 6 & Ibeshe & 10.2 & LatitudeN $06^{\circ} 35^{\prime} 05.1^{\prime \prime}$, Longitude E $003^{\circ} 29^{\prime} 02.0^{\prime \prime}$ \\
\hline 7 & Owode Ilaje & 3.3 & LatitudeN $06^{\circ} 34^{\prime} 11.6^{\prime \prime}$, Longitude E $003^{\circ} 28^{\prime} 30.1^{\prime \prime}$ \\
\hline 8 & Ofin I & 3.1 & LatitudeN $06^{\circ} 33^{\prime} 56.6^{\prime \prime}$, Longitude E $003^{\circ} 28^{\prime} 20.3^{\prime \prime}$ \\
\hline 9 & Ofin II & 3.7 & LatitudeN $06^{\circ} 33^{\prime} 06.8^{\prime \prime}$, Longitude E $003^{\circ} 28^{\prime} 22.7^{\prime \prime}$ \\
\hline 10 & Oreta & 14.0 & LatitudeN $06^{\circ} 32^{\prime} 40.6^{\prime \prime}$, Longitude E $003^{\circ} 28^{\prime} 44.2^{\prime \prime}$ \\
\hline
\end{tabular}

Table 1. Sampling locations and their coordinates.
Simpson's dominance index

Simpson's dominance index (C) (Ogbeibu, 2005).

$$
\mathrm{C}=\Sigma\left(\frac{\mathrm{ni}}{\mathrm{N}}\right)^{2}
$$

Where:

$\mathrm{C}=$ dominance index;

$\mathrm{n}=$ the total number of organisms of a species;

$\mathrm{N}=$ the total number of organisms of all species.

\section{RESULTS AND DISCUSSION}

\section{Hydrochemistry}

The mean values of the physico-chemical parameters in water measured at the study stations during the period of study are shown in Table 2. The spatiotemporal variations in the values of major parameters measured during the study are represented in Figures 2-9. The relatively high salinity and conductivity values recorded in all the study stations are indicative of the season of study. Nwankwo (1994) has classified the hydrological season in Nigeria into two; the dry season (November to April) and the rainy season (May to October). The period of the current study falls into the category of the dry season. The high evaporation of the surface water and the reduction in the introduction of fresh water through precipitation or run-off, could have contributed to the high values in salinity, conductivity and total dissolved solids in the study area (Nkwoji et al., 2010).

The mean values of the water temperatures and $\mathrm{pH}$ across the study stations showed very little or no variations (Table 2). This agrees with Nkwoji (2016) that surface water temperature in the Tropics is conservative and could only vary significantly with seasons. The $\mathrm{pH}$ range of the water (6.48 to 7.00) was also conservative (Nkwoji et al., 2010). There was no significant $(P<0.05)$ difference in the $\mathrm{pH}$ values at the study stations (Table 2). Such study stations as Majidun Entrance (Station 2), Ibeshe (Station 6) and Oreta (Station 10) recorded higher turbidity and total suspended solids (TSS). These stations are areas of high level of dredging and sediment mining. Stations 2 and 6 also recorded lower dissolved oxygen values. This could be attributed to the reduction in photosynthetic activities as a result of increase in the concentration of suspended particulate matters in the water (Edokpayi and Nkwoji, 2007). In general, the dissolved oxygen concentrations across the stations are not below of $5.0 \mathrm{mg} / \mathrm{L}$ 

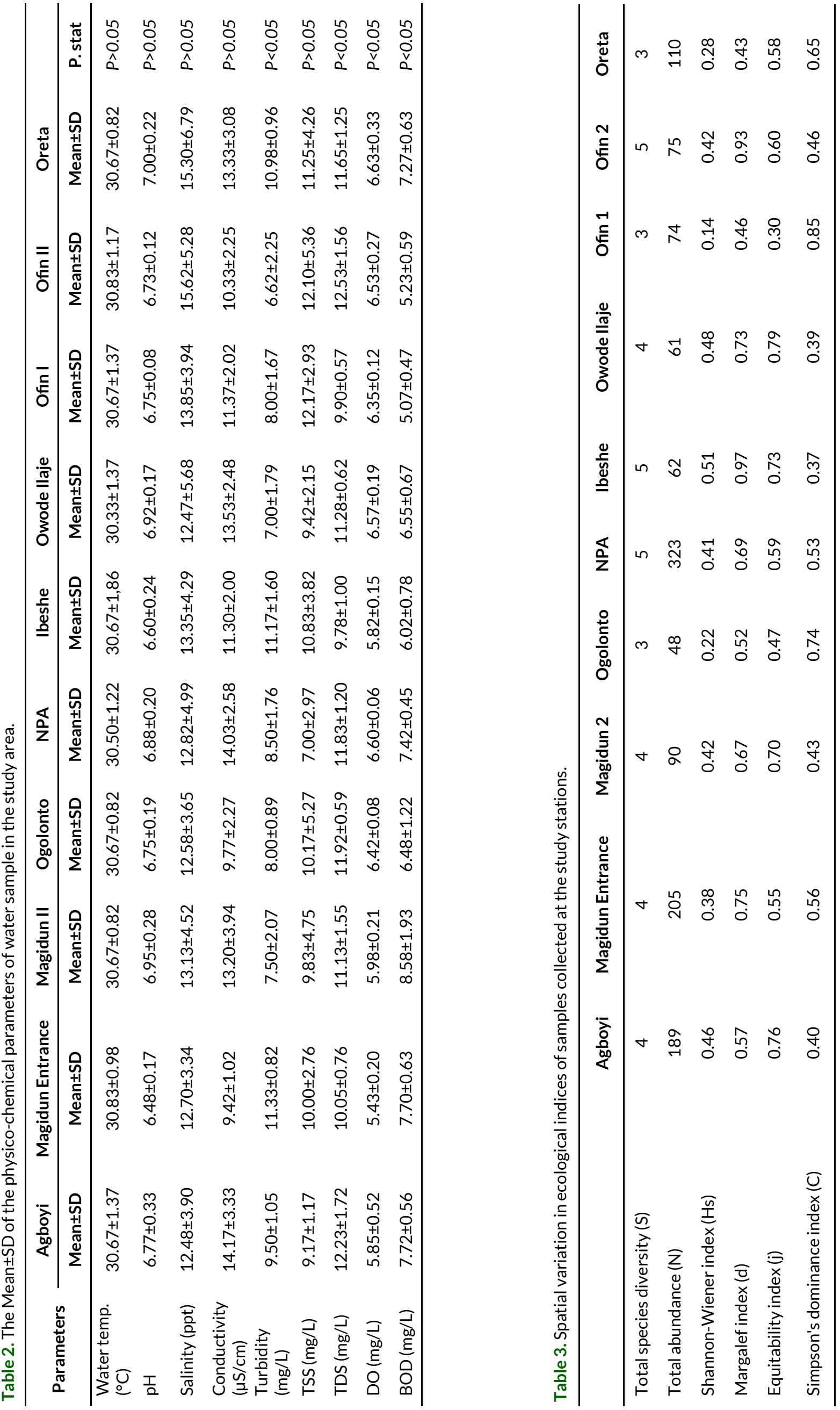
stipulated as minimum level for normal aquatic life by Federal Ministry of Environment of Nigeria (Odiete, 1999). The analysis of variance showed significant $(P<0.05)$ differences in the values of turbidity and dissolved oxygen in the study stations. Although the analysis of variance indicated no significant $(P<0.05)$ difference in total suspended solids values among the study stations, the Post Hoc Tests of Multiple Comparison showed significant $(P<0.05)$ difference in TSS values between Stations 2, 6 and 10 on one side, and the other stations on the other side.

\section{Sediment grain size analysis}

The mean spatial variation in sediment grain size of the study area is presented in the Figure 9. The sediment particle is dominated by sand grains. This is at variance with previous studies on the sediment type of the Lagos lagoon. Ajao and Fagade (1991) and Nkwoji et al. (2011) worked on the sediments of Lagos lagoon and posit that the lagoon has predominantly muddy sediment. The dredging of the lagoon, and the indiscriminate mining of the muddy top substratum, and the consequent exposure of the sandy, subsurface substratum may be responsible for the change in sediment characteristics. The only study station that has higher percentage of its sediment composition as mud is Station 10 . The station was highly dredged and relatively deeper that the other stations. Siltation from the surrounding shallower mud substrates may have resulted in muddy top sediment recorded. The most obvious effect of sediment mining on the water quality of any water body is the suspension of sediment particles in the water column and these results to increased turbidity.

Macrobenthic community structure

The community structure of the macrozoobenthos sampled during the period of study is presented in Table 3. Species abundance was highest in Station 5 (NPA), Station 1 (Agboyi) and

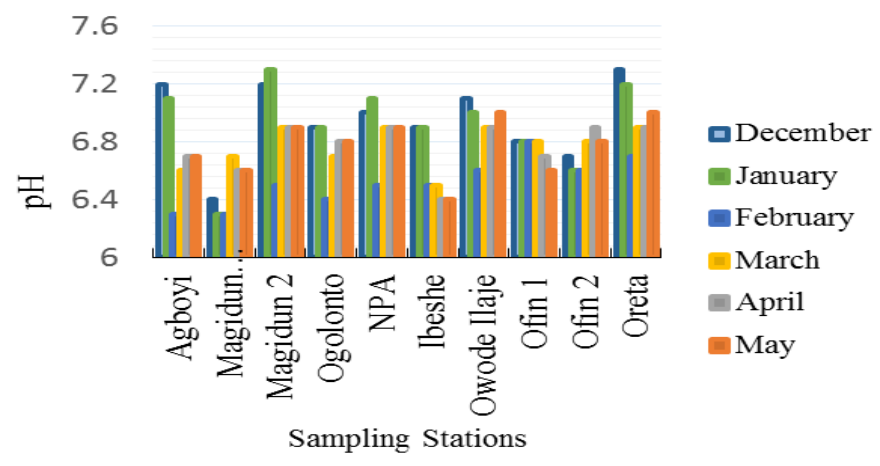

Figure 2. Spatiotemporal variation in $\mathrm{pH}$ values.

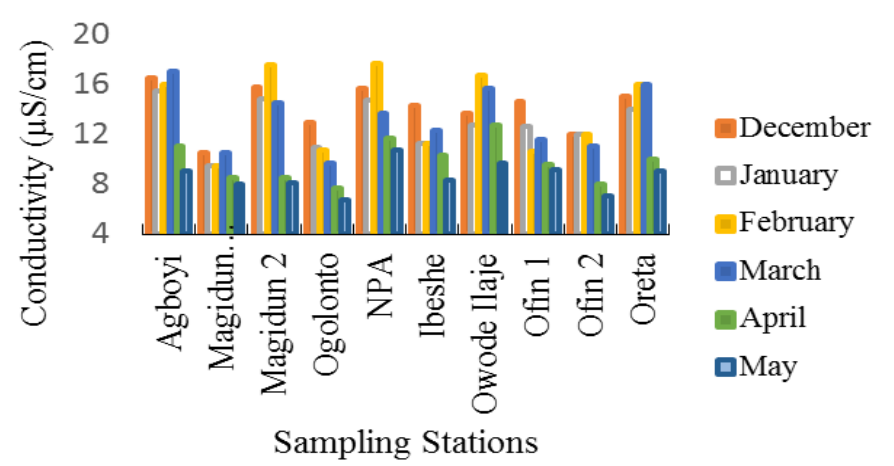

Figure 4. Spatiotemporal variation in conductivity
Station 9 (Ofin2) study stations while number of individuals sampled was highest in Station 5 and least in Station 4 (Ogolonto). The general low abundance in macrozoobenthos assemblage could be attributed to habitat distortion and destruction occasioned by the dredging of the lagoon and indiscriminate sediment mining in the study area. The maximum species diversity and richness indices, 0.51 and 0.97 respectively, recorded in this study are very low compared to what have been reported previously from the Lagos lagoon and some other coastal waters in Nigeria (Yakub and Igbo, 2014; Nkwoji et al., 2010; Edokpayi and Nkwoji, 2007).

The percentage contribution of taxa to the overall macrozoobenthos community is presented in Figure 10. The bivalve mollusc, Aloides trigona contributed the highest (54\%), followed by the gastropod mollusc, Pachymelania aurita (35\%). The polychaetous annelids, Capitella capitata and Nereis sp., the crustacean, Clibanarius africanus and Sersama huzerdii, and the bivalve Crassostrea gazar, contributed less than $1 \%$ each to the benthic macrofauna sampled during the period of study. The very low abundance of the crustaceans in this study could be indicator to the stressed nature of the study area. Nkwoji et al. (2016) have identified the crustacean species as sensitive to stressed environment.

The spatial percentage contribution and to the overall benthic macrofauna assemblage in the study area is represented in Figure 11. The relatively high abundance of the benthic organisms recorded in Station 5 could be attributed to the fact that this station was restricted from the indiscriminate sediment mining prevalent in the study area. Although Station 9 recorded lower numeric abundance, the diversity and richness indices are relatively high. Stations 1 and 5 recorded relatively high species and numeric abundance. The stations also recorded high diversity and richness indices. There were no activities of dredging and sediment mining in these study stations as at the period of this research.

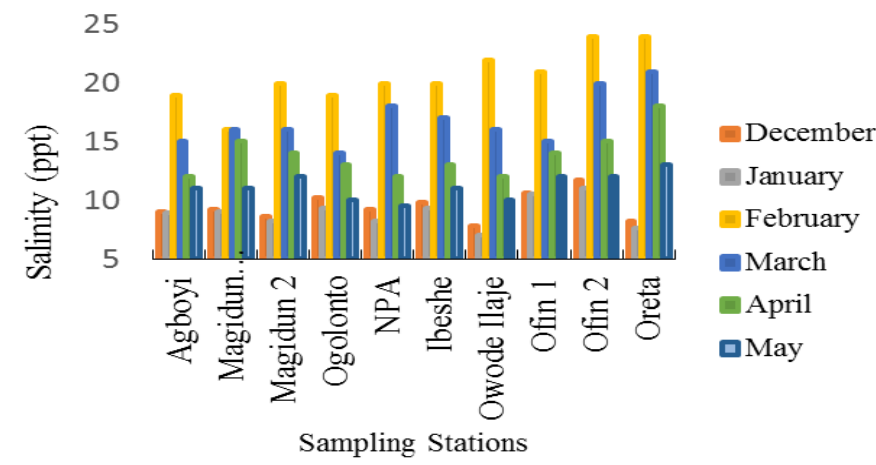

Figure 3. Spatiotemporal variation of salinity.

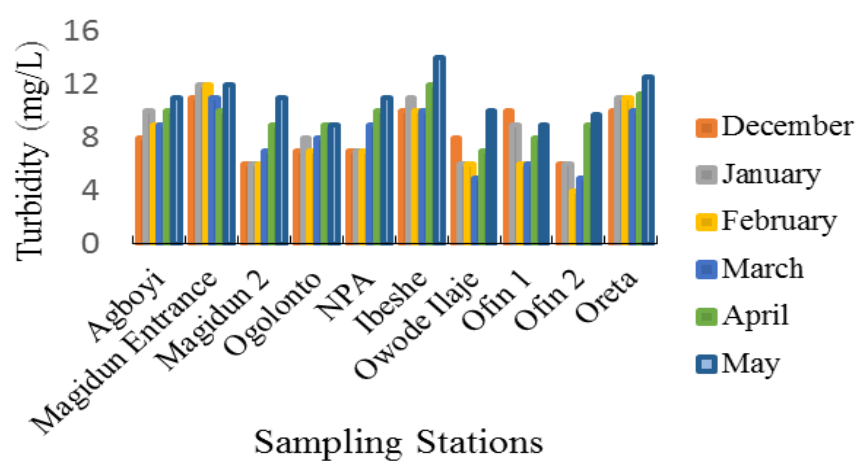

Figure 5. Spatiotemporal variation in Turbidity 
19

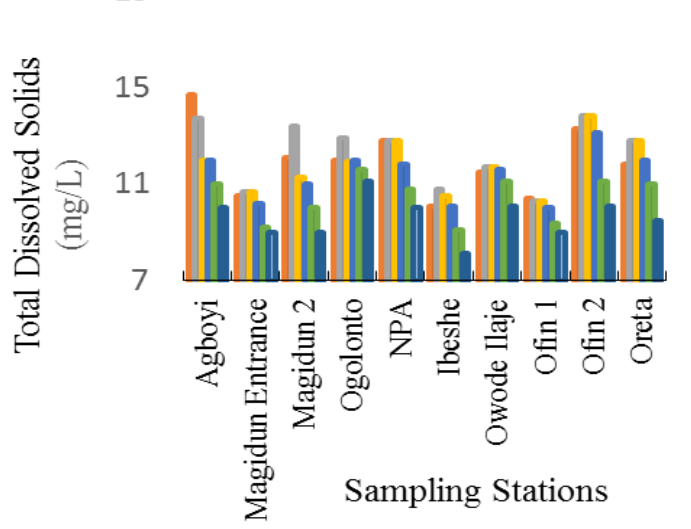

Figure 6. Spatiotemporal variation of total dissolved solids.

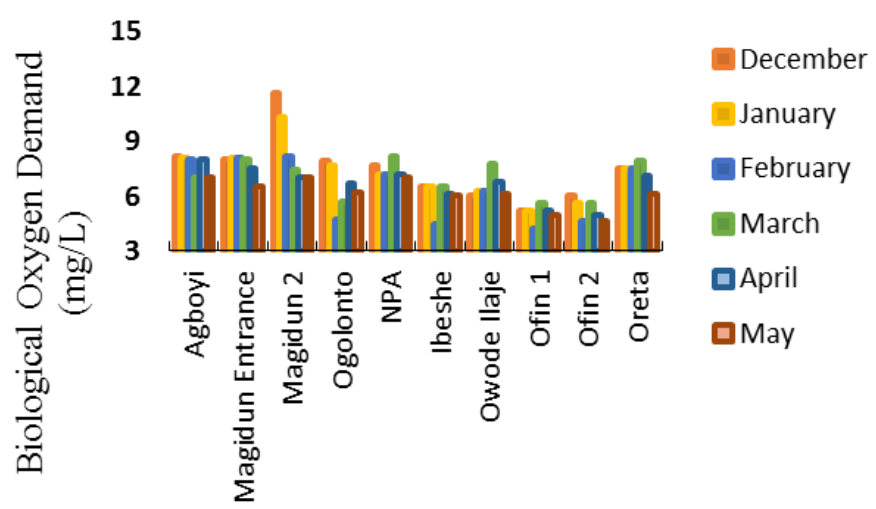

Sampling Stations

Figure 8. Spatiotemporal variation of biological oxygen demand .

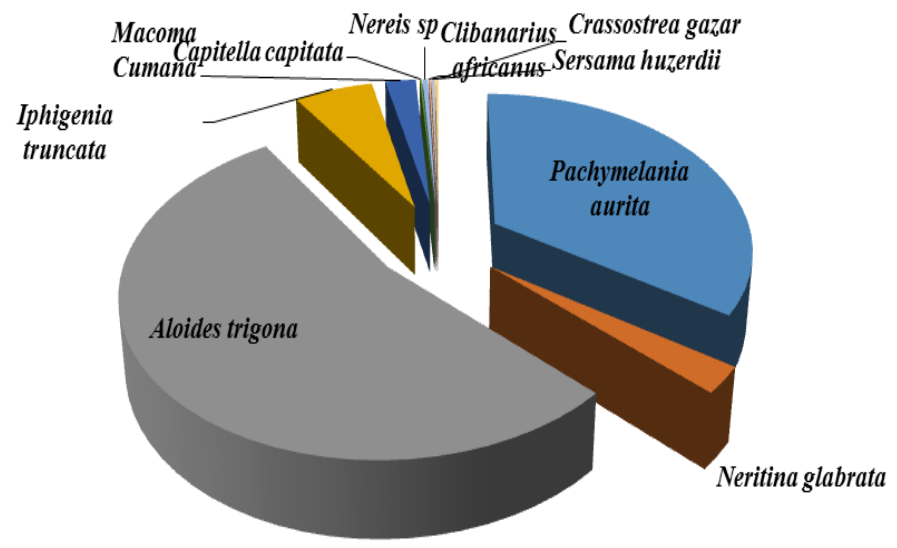

Figure 10. Taxa contributions to the overal macrobenthic fauna.

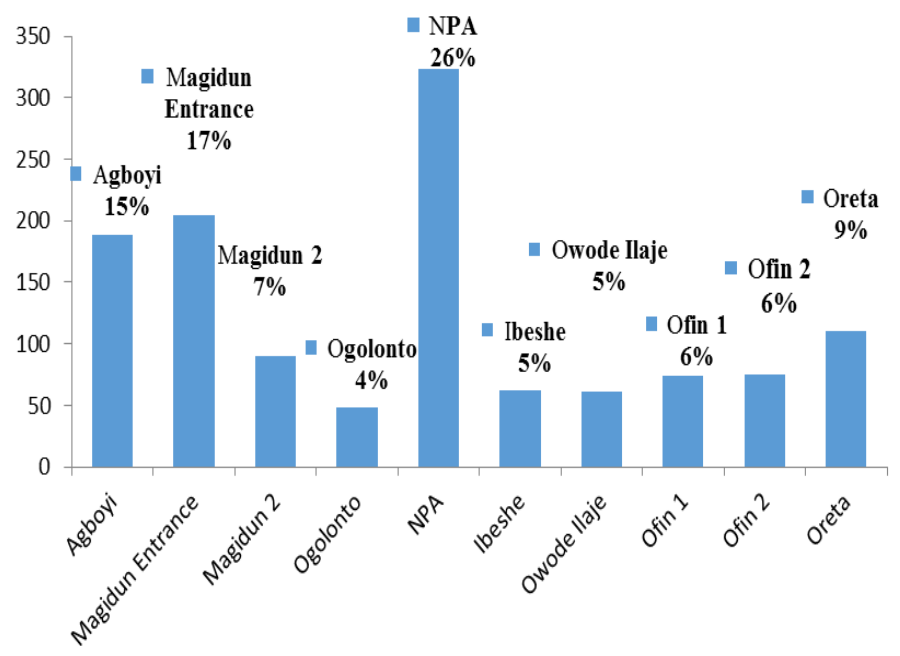

Figure 11. Spatial percentage distribution of benthic macrofauna.

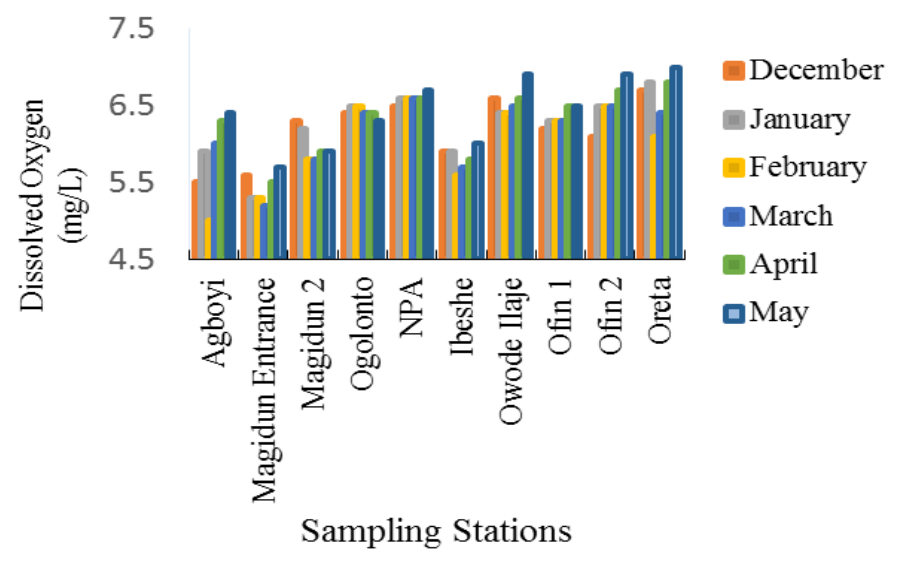

Figure 7. Spatiotemporal variation of dissolved oxygen.

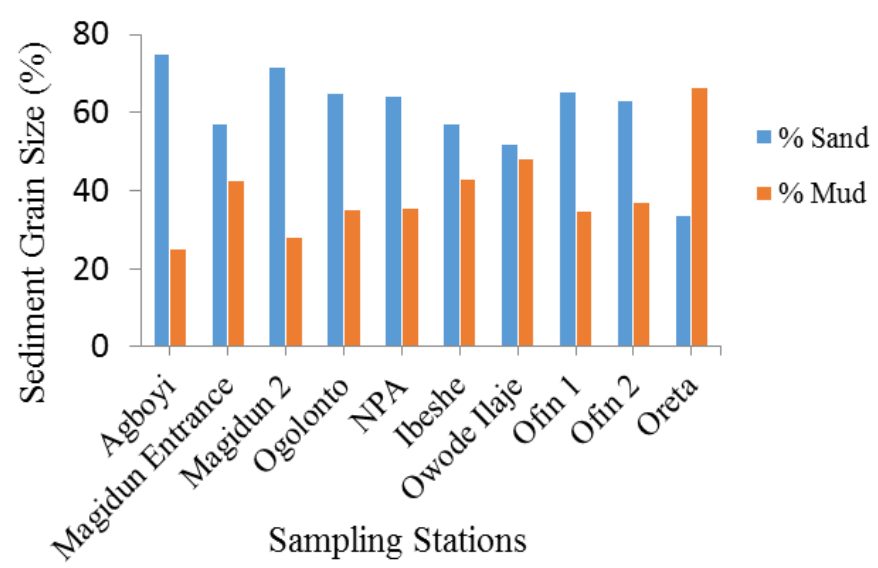

Figure 9. Mean spatial variation of sediment grain size.

\section{Conclusion}

The sediment mining increases the turbidity of the water and reduces the photosynthetic layer. Consequently, the dissolved oxygen of the water would reduce. Furthermore, the general physicochemical characteristics of the water would be altered and the health of the aquatic biota hampered. The benthic fauna are the worst hit. Their habitat is distorted and destroyed leading to defaunisation. Also, their pelagic larvae are buried by the settling sediment particles, leading to poor recruitment of the benthos. The role of the benthic fauna in the aquatic ecosystem cannot be over-emphasised. They are needed for a balanced energy transfer in the food web and their existence must be guaranteed by ensuring healthy water because their distribution and diversity correlate with the water quality. The benthic ecologists posit that the macrozoobenthos are reliable indices for assessing the stability and health of the aquatic ecosystem. The impact of sediment mining the water chemistry and the benthic fauna of Lagos lagoon is grave. There should be regulations backed with enforcements against this menace. Since the benthic fauna are the worst affected by this act, benthic studies should be intensified on the lagoon to buttress the negative impact and forestall the total collapse of this coastal body of water.

Open Access: This is open access article distributed under the terms of the Creative Commons Attribution License, which permits unrestricted use, distribution, and reproduction in any medium, provided the original author(s) and the source are credited. 


\section{REFERENCES}

Ajao, E.A. and Fagade, S.O. (1991).Study of the sediments and communities in Lagos Lagoon, Nigeria. Oil and Chemical Pollution. Elsevier Science Publishers Ltd., England. 75-117.

American Public Health Association (APHA), (2005). Standard methods for the examination of water and waste water, 20th ed. APHA, New York, pp. 1270.

Barnes, R.S.K. and Hughes, R.N. (1999). Introduction to marine ecology (3rd Edition), Wiley-Blackwell Publisher, pp. 296.

Chutter, F.M. (1969). The effects of silt and sand on the invertebrate fauna of streams and rivers. Hydrobiologia, 34(1): 57-76.

Covich, A.P., Palmer, M.A. and Crowl, T.A. (1999). The Role of Benthic Invertebrate Species in Freshwater Ecosystems. BioScience, 49(2): 119-127.

Edmunds, J. (1978). Sea Shells and other Molluscs Found on West African Coasts and Estuaries. Accra. Ghana University Press, pp. 146.

Edokpayi, C.A. and Nkwoji, J.A. (2007). Annual changes in the physico-chemical and macrobenthic invertebrate characteristics of the Lagos lagoon sewage dump site at Iddo, southern Nigeria. Ecology, Environment and Conservation, 13 (1): 13-18.

FAO (1981). Fisheries Survey in the Western and mid-Western Regions of Nigeria. FAO/sf.74/NIR6. pp. 142.

Fischer, W., Bianchi, G. and Scott, W.B. (1981). FAO species identification sheets for fisheries purposes. Eastern Central Atlantic: Fishing Areas 34 and Part of 47. Food and Agriculture Organization of the United Nations.

Hayward, P.J. and Ryland, J.S. (1995). Handbook of the Marine Fauna of North-East Europe. Oxford University Press, New York, pp. 591.

Mclntyre, A.D. and Warwick, R.M. (1984). Meiofauna Techniques. Heinemann Education Books Ltd.

Nkwoji, J.A., Yakub A.S., Abiodun, A.O. and Bello, B.O. (2016). Hydrochemistry and community structure of benthic macroinvertebrates in Ilaje coastal waters, Ondo State, Nigeria Regional Studies in Marine Science, 8: 7-13, http:// dx.doi.org/10.1016/j.rsma.2016.08.009

Nkwoji, J.A. and Edokpayi, C.A. (2013). Hydrochemistry and community structure of benthic macroinvertebrates of Lagos lagoon, Nigeria. Research Journal of Pharmaceutical, Biological and Chemical Sciences , 4(1): 1119-1131

Nkwoji, J.A., Igbo, J.K., Mojekwu, T.O., Obienu, J.A. and Adeleye, A.O. (2011). Hydrochemistry and sediment characteristics of western Lagos lagoon, Nigeria. Continental Journal of Environmental Sciences, 5 (2): 19-24.
Nkwoji, J.A., Yakub A., Ajani, G.E., Balogun, K.J., Renner, K.O., Igbo, J.K., Ariyo, A.A., and Bello, B.O. (2010). Seasonal variations in the water chemistry and benthic macroinvertebrates of a south western lagoon, Lagos, Nigeria. Journal of American Science, 6(3): 85-92, http://www. jofamericanscience.org/ journals/am-sci/am 0603/ 12_2084_ joseph_am0603_85_92.pdf

Nuttall, P.M. and Bielby, G.H. (1973). The effect of China clay wastes on stream invertebrates. Environmental Pollution, 5: 77-86, https://doi.org/10.1016/0013-9327(73)90013-X

Nwankwo, D.I. (1994). Hydrochemical properties and bottomdwelling diatoms of a Lagos lagoon sewage disposal site. Polish Archives of Hydrobiologia, 41(1): 35-47.

Odiete, W.O. (1999). Environmental Physiology of Animals and Pollution. Diversified Resources Ltd., Lagos, pp. 261.

Ogbeibu, A.E. (2005). Biostatistics: A Practical Approach to Research and Data Handling. Mindex Publishing Co. Ltd., Benin, Nigeria, pp. 264

Sogbamu, T.O., Nagy, E., Philips, D.H., Arit, V.M., Otitoloju, A.A. and Bury, NR. (2016). Lagos lagoon sediment organic extracts and polycyclic aromatic hydrocarbons induce embryotoxic, teratogenic and genotoxic effects in Danio rerio (zebrafish) embryos. Environmental Science and Pollution Research, 23 (14):14489-14501, https:// doi.org/10.1007/s11356-016-6490-y

Teixeira, T.P., Neves, L.M. and Araújo, F.G. (2012). Thermal impact of a nuclear power plant in a coastal area in southeastern Brazil: Effects of heating and physical structure on benthic cover and fish communities. Hydrobiologia, 684(1): 161175, https://doi.org/10.1007/s10750-011-0980-1

Van de Bund, W.J., Goedkoop, W. and Johnson, R.K. (1994). Effect of deposit-feeder activity on bacterial production and abundance in prl, 13: 532-539, https:// doi.org/10.2307/1467849

Wallace, J.B. and Webser, J.R. (1996). The role of macroinvertebrates in stream ecosystem function. Annual Review of Entomology, 41: 115-139, DOI: https://doi.org/10.1146/ annurev.en.41.010196.000555

Yakub, A.S. and Igbo, J.K. (2014). Assessment of benthic macroinvertebrate fauna of two contiguous coastal water bodies within barrier lagoon complex, western Nigeria. Journal of Environment and Human, 1 (2): 39-46, http://citeseerx.ist. psu. edu/viewdoc/download?doi= 10.1.1.872.3120\& rep= rep1\&type=pdf

Yankson, K and Kendall, M.A. (2001). A student's guide to the seashore of west Africa: marine biodiversity capacity building in the west African sub-region. 132. 